\title{
TRANSATLANTIC DEVELOPMENTAL MIGRATIONS OF LOGGERHEAD SEA TURTLES DEMONSTRATED BY mtDNA SEQUENCE ANALYSIS
}

\author{
Alan B. Bolten, ${ }^{1,2}$ Karen A. Buorndal, ${ }^{1,2}$ Helen R. Martins, ${ }^{3}$ Thomas Dellinger, ${ }^{4}$ \\ Manuel J. Biscoito, ${ }^{5}$ SAndra E. EnCAlada, ${ }^{6}$ And Brian W. Bowen ${ }^{1,7}$ \\ ${ }^{1}$ Archie Carr Center for Sea Turtle Research, Box 118525, University of Florida, Gainesville, Florida 32611 USA \\ ${ }^{2}$ Department of Zoology, Box 118525, University of Florida, Gainesville, Florida 32611 USA \\ ${ }^{3}$ University of the Azores, Department of Oceanography and Fisheries, P-9900 Horta, Azores, Portugal \\ ${ }^{4}$ Universidade da Madeira, Largo do Município, Colégio dos Jesuitas, P-9000 Funchal, Madeira, Portugal \\ ${ }^{5}$ Museu Municipal do Funchal, Rua da Mouraria, 31, P-9000 Funchal, Madeira, Portugal \\ ${ }^{6}$ Interdisciplinary Center for Biotechnology Research, Box 110580, University of Florida, \\ Gainesville, Florida 32611 USA \\ ${ }^{7}$ Department of Fisheries and Aquatic Sciences, University of Florida, 7922 NW 71 st Street, \\ Gainesville, Florida 32653 USA
}

\begin{abstract}
Molecular markers based on mitochondrial (mt) DNA control region sequences were used to test the hypothesis that juvenile loggerhead sea turtles (Caretta caretta) in pelagic habitats of the eastern Atlantic are derived from nesting populations in the western Atlantic. We compared mtDNA haplotypes from 131 pelagic juvenile turtles ( 79 from the Azores and 52 from Madeira) to mtDNA haplotypes observed in major nesting colonies of the Atlantic Ocean and Mediterranean Sea. A subset of 121 pelagic samples $(92 \%)$ contained haplotypes that match mtDNA sequences observed in nesting colonies. Maximum likelihood analyses (UCON, SHADRACQ) estimate that $100 \%$ of these pelagic juveniles are from the nesting populations in the southeastern United States and adjacent Yucatan Peninsula, Mexico. Estimated contributions from nesting populations in south Florida $(0.71,0.72)$, northern Florida to North Carolina $(0.19,0.17)$, and Quintana Roo, Mexico $(0.11,0.10)$ are consistent with the relative size of these nesting aggregates. No contribution was detected from nesting colonies in the Mediterranean (Greece) or South Atlantic (Brazil), although samples sizes are insufficient to exclude these locations with finality. The link between west Atlantic nesting colonies and east Atlantic feeding grounds provides a more complete scientific basis for assessing the impact of subadult mortality in oceanic fisheries. Demographic models for loggerhead turtles in the western Atlantic can now be improved by incorporating growth and mortality data from juvenile turtles in pelagic habitats. These data demonstrate that the appropriate scale for loggerhead turtle conservation efforts is vastly larger than the current scale of management plans based on political boundaries.
\end{abstract}

Key words: Atlantic Ocean; Azores; Caretta caretta; conservation genetics; genetic markers; Madeira; marine turtles; migration; mitochondrial DNA sequencing; mixed stock analysis; population structure; regional management.

\section{INTRODUCTION}

Management of populations of migratory species requires knowledge of the distribution of each population, identification of the jurisdictions ("range states") through which the population passes, and cooperation among range states for regional management plans. These needs are difficult to achieve for sea turtles, with their extensive and largely obscure migration patterns. Over the past 40 years, the long migrations (sometimes involving thousands of kilometers) undertaken by mature individuals between foraging grounds and nesting beaches have been documented (Meylan 1982, Limpus et al. 1992). In addition to these reproductive migrations, juvenile turtles undertake extensive migrations, in both distance and time, that carry them to very dif-

Manuscript received 2 October 1996; revised 22 May 1997; accepted 16 June 1997. ferent habitats than those inhabited by adults. Scientists are just beginning to grasp the magnitude and to chart the routes of these developmental migrations, which may last for decades and carry the turtles across ocean basins (Bolten and Balazs 1995, Bowen et al. 1995).

The largest nesting aggregation of loggerhead sea turtles (Caretta caretta) in the Atlantic, if not in the world, is in the southeastern United States, where 〜50000-70000 clutches are deposited every year (Meylan et al. 1995), with a mean clutch size of 115 eggs (Ehrhart 1982). After the 5-cm hatchlings emerge and enter the ocean, they are not observed again in the western Atlantic until 50-cm juveniles appear in benthic foraging areas. This "mystery of the lost year" intrigued biologists for many years (Carr 1982). Shortly before his death, Archie Carr (1986), following suggestions in Brongersma (1972), hypothesized that, during this "missing" life stage, juvenile turtles inhabit 


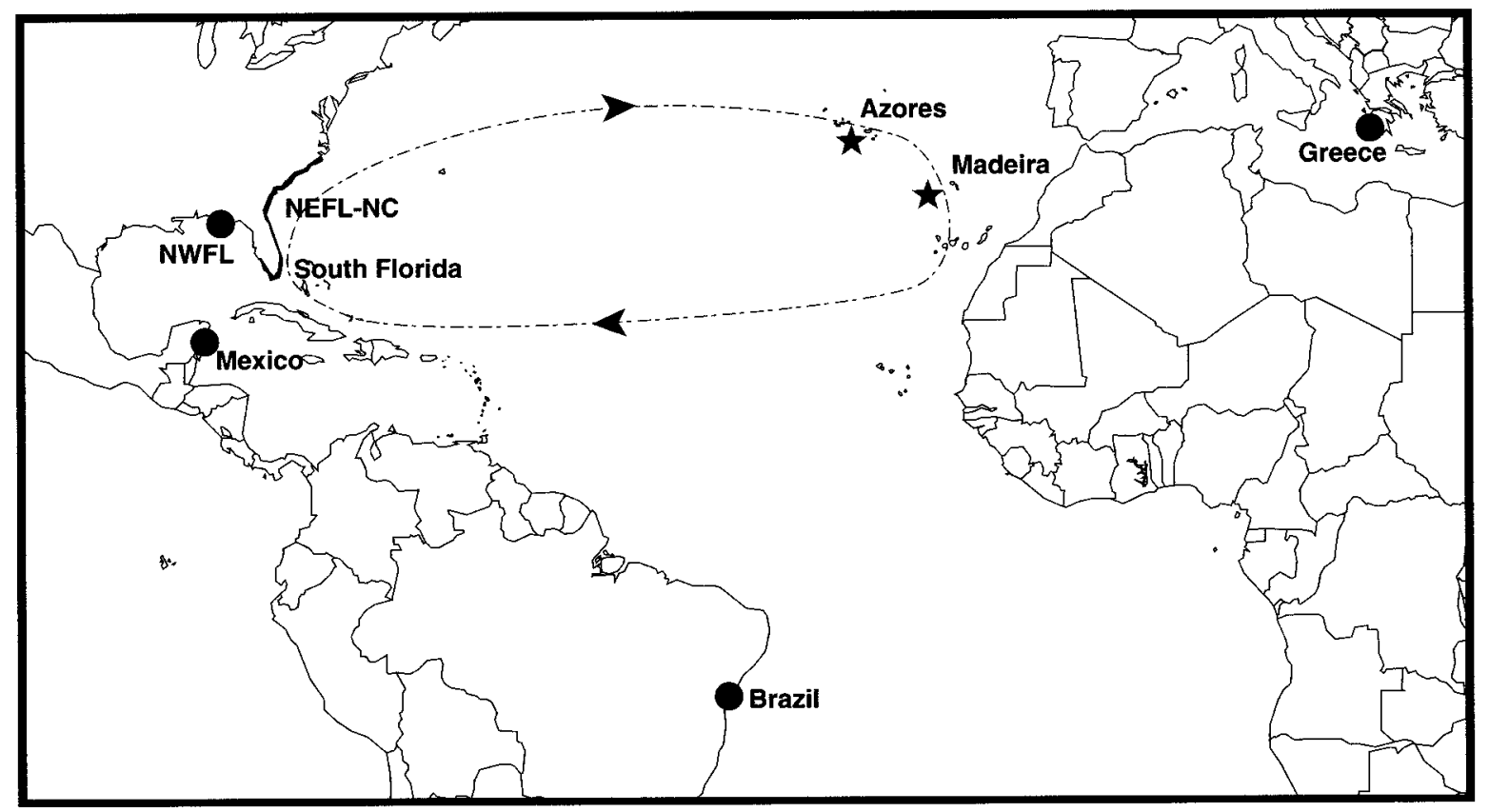

FIG. 1. Map showing locations of six nesting populations of loggerhead sea turtles: northeast Florida to North Carolina (NEFL-NC), south Florida, northwest Florida (NWFL), Mexico, Brazil, and Greece. The two pelagic sampling sites (Azores and Madeira) are indicated with stars. Arrows show the North Atlantic gyre.

the pelagic zone of the North Atlantic gyre system. Carr (1986) suggested that posthatchlings are transported by this gyre system around the Atlantic, and that the small loggerheads reported to occur in large numbers in the eastern Atlantic around the Azores and Madeira (Brongersma 1972) are derived from the nesting beaches in the western Atlantic. To date, the major line of evidence in support of this hypothesis is the complementary nature of the size distributions of loggerheads from the western and eastern Atlantic (Carr 1986, Bolten et al. 1993). Additional support for this hypothesis comes from captures in the western Atlantic of five juvenile loggerheads tagged in the eastern Atlantic (Bolten et al. 1992a; A. B. Bolten and K. A. Bjorndal, unpublished data), and from the evidence that some juvenile loggerheads in the western Mediterranean are derived from western Atlantic nesting populations (Bowen et al. 1993, Laurent et al. 1993, Bowen 1995b).

In recent years, genetic markers have provided a valuable tool for elucidating the distribution of migratory marine populations (Avise 1994, Baker et al. 1994). Genetic tags have been used to identify the sources for mixed populations sampled away from breeding areas in migratory species such as salmon (Smouse et al. 1990) and sea turtles (Broderick et al. 1994, Bowen 1995a, $b$, Bowen et al. 1995, 1996, Sears et al. 1995). In most species of sea turtles, females return to nest in the vicinity of their natal beach (Bowen 1995a). The high degree of site fidelity on the part of nesting females results in genetically discrete popu- lations that are distinct demographic (and management) units. When turtles leave the breeding areas, however, reproductive populations may become mixed on foraging grounds (Carr 1975, Bowen 1995b), and the distinctions among management units are obscured. If the source of individuals is unknown, it is difficult or impossible to evaluate the effects of exploitation or of management actions. This is particularly true if the potential source populations differ substantially in size or conservation outlook, as is the case with Atlantic loggerhead turtles.

In a companion study (Encalada et al., in press), the population structure of nesting aggregations of Atlantic loggerheads has been evaluated based on mitochondrial (mt) DNA control region sequences. That study identified six demographically independent nesting populations and provided the genetic markers necessary to evaluate the sources of juvenile loggerheads in pelagic feeding grounds. In this study, we have analyzed mtDNA sequences for 131 juvenile loggerheads captured in pelagic habitats around the Azores and Madeira, to test the hypothesis that juvenile loggerheads in the eastern Atlantic are derived from nesting populations in the western Atlantic. From our results, we define the geographic range over which management policies must be integrated.

\section{Methods}

Sampling sites for nesting and pelagic populations are shown in Fig. 1. Details of nesting-beach samples and haplotype data are available in Encalada et al. (in 
press). Juvenile loggerheads were captured by hand or dip net from the surface of the ocean around the Azores $(n=79)$ and Madeira $(n=52)$. Sampling sites in the Azores and Madeira are separated by $\geq 1100 \mathrm{~km}$. Blood samples were collected from the dorsal cervical sinus of 64 Azores turtles and all Madeira turtles. Blood was preserved in lysis buffer [ $100 \mathrm{mmol} / \mathrm{L}$ Tris-HCl, $\mathrm{pH} 8$; $100 \mathrm{mmol} / \mathrm{L}$ EDTA, pH $8 ; 10 \mathrm{mmol} / \mathrm{L} \mathrm{NaCl} ; 0.5 \%$ (mass per volume) sodium dodecyl sulfate (White and Densmore 1992)] in a 1:10 ratio of blood to buffer. In addition, packed blood cells from 10 Azores loggerheads were frozen in liquid nitrogen, and muscle samples from five loggerheads that stranded dead in the Azores were minced and preserved in lysis buffer. Curved carapace length of the turtles ranged from 9 to $71 \mathrm{~cm}$ for the Azores sample and from 20 to $55 \mathrm{~cm}$ for the Madeira sample.

DNA isolations were conducted with standard phenol/chloroform methodology (Hillis et al. 1996), and mtDNA control region sequences were amplified via polymerase chain reaction methodology (PCR; Mullis and Faloona 1987) using primers TCR-5 and TCR-6 in Norman et al. (1994). An 18-base "universal" M13 sequence was added to the 5 ' end of primers to facilitate automated sequencing. The PCR amplifications included one step at $94^{\circ} \mathrm{C}$ (3 min), followed by 35 cycles at $94^{\circ} \mathrm{C}(1 \mathrm{~min}), 50^{\circ} \mathrm{C}(1 \mathrm{~min})$, and $72^{\circ} \mathrm{C}(1 \mathrm{~min})$. Standard precautions, including negative controls (template-free PCR reactions), were used to test for contamination and to assure the fidelity of PCR reactions.

Streptavidin-coated magnetic beads (Dynabeads M280 streptavidin, Dynal, Sweden) were used to purify PCR products (Mitchell and Merrill 1989). Singlestranded template was generated by denaturing the magnetically captured double-stranded DNA with fresh $0.15 \mathrm{~mol} / \mathrm{L} \mathrm{NaOH}$, and using the released (nonbiotinylated) strand as a template for sequencing reactions. Single-stranded sequencing reactions were conducted with fluorescently labelled M13 primers in a robotic work station (Applied Biosystems model 800, PerkinElmer Corporation, Applied Biosystems Division, Foster City, California, USA), following a dye-primer protocol. DNA sequencing was accomplished with a modified version of the procedure described by Sanger et al. (1977).

Sequences that matched known haplotypes were collated for analysis, whereas new or ambiguous genotypes were sequenced in the opposite direction to assure accuracy. At least one representative for every haplotype was sequenced in both directions. Samples from the pelagic study sites that matched known rookery haplotypes (A-J) were assigned a letter code, following Encalada et al. (in press). New haplotypes observed only in the feeding population were assigned letters $\mathrm{K}-\mathrm{Q}$.

To determine whether samples from the two pelagic study sites were part of the same migratory cohort, we compared haplotype frequencies of the Azores and Madeira samples with chi-square tests using the computer program CHIRXC (Zaykin and Pudovkin 1993), which calculates probabilities of independence using a Monte Carlo simulation. The chi-square test was also used to test for differences in haplotype frequency among size classes.

The six loggerhead nesting populations in the Atlantic used to evaluate source populations were northwest Florida $(n=42)$, south Florida $(n=50)$, and northeast Florida to North Carolina $(n=105)$ in the United States; Quintana Roo, Mexico $(n=20)$; Kiparissia Bay, Peloponnesus Island, Greece $(n=21)$; and Bahia, Brazil $(n=11)$ (Encalada et al., in press). Relative contributions from the six nesting populations to the population of pelagic juvenile loggerheads were estimated using unconditional maximum likelihood analyses (Pella and Milner 1987) with the computer programs UCON (M. Masuda, NMFS Auke Bay Lab, 11305 Glacier Highway, Juneau, Alaska 99801 USA) and SHADRACQ (Xu et al. 1994). Standard deviations of estimates of relative contributions were calculated with the "jackknife" option in UCON.

\section{RESUlts AND Discussion}

\section{Haplotype frequencies}

For each pelagic loggerhead sample, we analyzed a 380-base pair fragment of the mtDNA control region, corresponding to the region flanked by primers TR-5 and TR-6 (Norman et al. 1994). Thirty-three polymorphic sites were observed in Atlantic loggerheads (rookery and feeding ground surveys; Table 1) defining 17 haplotypes, 10 of which (A-J in Table 2) are known from the nesting-population survey (Encalada et al., in press), and seven of which (K-Q in Table 2) are observed only in the feeding-ground samples. Of the 131 pelagic loggerheads, $121(92 \%)$ had haplotypes that were known from nesting populations.

A parsimony network of the relationships among the 17 haplotypes (Fig. 2) indicates two groups of closely related haplotypes: one clustered around haplotype $\mathrm{B}$ and one around haplotypes A and D. Haplotypes A, B, and $\mathrm{D}$ are three of the most common haplotypes in loggerhead nesting populations (Table 2; Encalada et al., in press). The new haplotypes $(\mathrm{K}-\mathrm{Q})$ found in pelagic juvenile loggerheads are very similar to haplotypes recorded from nesting populations (Fig. 2). All differ from a known nesting-population haplotype by only one nucleotide substitution.

Haplotype frequencies in the Azores and Madeira samples were not significantly different $\left(\chi^{2}=12.881\right.$, df $=11, P=0.269)$; therefore, the samples were combined for subsequent analyses. Haplotype frequencies were also homogeneous among $10-\mathrm{cm}$ size classes of the pelagic turtles $\left(\chi^{2}=37.313\right.$, df $\left.=55, P=0.948\right)$, indicating consistency in genetic composition among size/age classes in the pelagic population.

Maximum likelihood (ML) analyses have been used to estimate contributions from potential source rook- 
TABLE 1. Thirty-three polymorphic sites observed in Atlantic loggerheads (rookery and feeding ground surveys) based on a 380-base-pair fragment of the mtDNA control region. Sequence numbering begins at the $5^{\prime}$ end of primer TCR-5 (Norman et al. 1994).

\begin{tabular}{|c|c|c|c|c|c|c|c|c|c|c|c|c|c|c|c|c|c|c|c|c|c|c|c|c|c|c|c|c|c|c|c|c|c|}
\hline \multirow[b]{2}{*}{$\begin{array}{c}\text { Haplotype } \\
\text { letter } \\
\text { code }\end{array}$} & \multicolumn{33}{|c|}{ Polymorphic sites } \\
\hline & $\begin{array}{l}3 \\
2\end{array}$ & $\begin{array}{l}3 \\
5\end{array}$ & $\begin{array}{l}3 \\
7\end{array}$ & $\begin{array}{l}5 \\
1\end{array}$ & $\begin{array}{l}5 \\
3\end{array}$ & $\begin{array}{l}6 \\
3\end{array}$ & $\begin{array}{l}7 \\
8\end{array}$ & $\begin{array}{l}9 \\
6\end{array}$ & $\begin{array}{l}1 \\
0 \\
4\end{array}$ & $\begin{array}{l}1 \\
6 \\
1\end{array}$ & $\begin{array}{l}1 \\
6 \\
2\end{array}$ & $\begin{array}{l}1 \\
7 \\
0\end{array}$ & $\begin{array}{l}1 \\
8 \\
8\end{array}$ & $\begin{array}{l}2 \\
1 \\
0\end{array}$ & $\begin{array}{l}2 \\
1 \\
6\end{array}$ & $\begin{array}{l}2 \\
3 \\
0\end{array}$ & $\begin{array}{l}2 \\
4 \\
4\end{array}$ & $\begin{array}{l}2 \\
4 \\
6\end{array}$ & $\begin{array}{l}2 \\
5 \\
9\end{array}$ & $\begin{array}{l}2 \\
9 \\
4\end{array}$ & $\begin{array}{l}3 \\
1 \\
2\end{array}$ & $\begin{array}{l}3 \\
1 \\
4\end{array}$ & $\begin{array}{l}3 \\
1 \\
5\end{array}$ & $\begin{array}{l}3 \\
1 \\
7\end{array}$ & $\begin{array}{l}3 \\
2 \\
1\end{array}$ & $\begin{array}{l}3 \\
2 \\
7\end{array}$ & $\begin{array}{l}3 \\
5 \\
5\end{array}$ & $\begin{array}{l}3 \\
5 \\
6\end{array}$ & $\begin{array}{l}3 \\
5 \\
7\end{array}$ & $\begin{array}{l}3 \\
5 \\
8\end{array}$ & $\begin{array}{l}3 \\
5 \\
9\end{array}$ & $\begin{array}{l}3 \\
6 \\
0\end{array}$ & $\begin{array}{l}3 \\
6 \\
3\end{array}$ \\
\hline A & $\mathrm{T}$ & G & $\mathrm{T}$ & $\mathrm{T}$ & $\mathrm{T}$ & A & $\mathrm{G}$ & $A$ & $A$ & $\mathrm{C}$ & G & $A$ & $\mathrm{G}$ & $\mathrm{C}$ & $\mathrm{T}$ & $\mathrm{C}$ & G & $\mathrm{C}$ & $A$ & - & $\mathrm{A}$ & $\mathrm{A}$ & $\mathrm{T}$ & A & $\mathrm{A}$ & $\mathrm{C}$ & - & - & - & - & - & - & A \\
\hline B & $\mathrm{C}$ & $\mathrm{A}$ & $\mathrm{C}$ & $\mathrm{C}$ & - & $\mathrm{G}$ & $\mathrm{G}$ & A & $\mathrm{G}$ & $\mathrm{T}$ & $\mathrm{A}$ & $\mathrm{A}$ & G & $\mathrm{T}$ & $\mathrm{T}$ & $\mathrm{T}$ & $\mathrm{A}$ & $\mathrm{T}$ & G & G & $\mathrm{A}$ & $\mathrm{G}$ & $\mathrm{C}$ & $\mathrm{G}$ & $\mathrm{A}$ & $\mathrm{T}$ & $\mathrm{G}$ & $\mathrm{C}$ & A & $\mathrm{A}$ & $\mathrm{G}$ & $\mathrm{T}$ & A \\
\hline $\mathrm{C}$ & $\mathrm{C}$ & A & C & $\mathrm{C}$ & - & $\mathrm{G}$ & $\mathrm{G}$ & A & $\mathrm{G}$ & $\mathrm{T}$ & A & $A$ & A & $\mathrm{T}$ & $\mathrm{T}$ & $\mathrm{T}$ & A & $\mathrm{T}$ & $\mathrm{G}$ & G & $\mathrm{A}$ & $\mathrm{G}$ & $\mathrm{C}$ & $\mathrm{G}$ & A & $\mathrm{T}$ & $\mathrm{G}$ & $\mathrm{C}$ & A & $\mathrm{A}$ & $\mathrm{G}$ & $\mathrm{T}$ & A \\
\hline D & $\mathrm{T}$ & G & $\mathrm{T}$ & $\mathrm{T}$ & $\mathrm{T}$ & A & $\mathrm{G}$ & A & A & $\mathrm{C}$ & $\mathrm{A}$ & $\mathrm{A}$ & $\mathrm{G}$ & $\mathrm{C}$ & $\mathrm{T}$ & $\mathrm{C}$ & $\mathrm{A}$ & $\mathrm{C}$ & $\mathrm{A}$ & - & $\mathrm{A}$ & $\mathrm{A}$ & $\mathrm{T}$ & A & $\mathrm{A}$ & $\mathrm{C}$ & - & - & - & - & - & - & A \\
\hline $\mathrm{E}$ & $\mathrm{C}$ & $A$ & $\mathrm{C}$ & $\mathrm{C}$ & - & $\mathrm{G}$ & G & A & $\mathrm{G}$ & $\mathrm{T}$ & $\mathrm{A}$ & $\mathrm{A}$ & $\mathrm{G}$ & $\mathrm{T}$ & $\mathrm{T}$ & $\mathrm{T}$ & $\mathrm{A}$ & $\mathrm{T}$ & G & G & $A$ & $\mathrm{G}$ & $\mathrm{C}$ & $\mathrm{G}$ & $\mathrm{A}$ & $\mathrm{T}$ & G & $\mathrm{C}$ & A & $A$ & $\mathrm{G}$ & $\mathrm{T}$ & - \\
\hline $\mathrm{F}$ & $\mathrm{C}$ & A & $\mathrm{C}$ & $\mathrm{C}$ & - & $\mathrm{G}$ & G & A & G & $\mathrm{T}$ & $\mathrm{A}$ & $\mathrm{A}$ & G & $\mathrm{T}$ & $\mathrm{T}$ & $\mathrm{T}$ & $\mathrm{A}$ & $\mathrm{T}$ & $\mathrm{G}$ & G & $\mathrm{A}$ & $\mathrm{G}$ & C & $\mathrm{G}$ & - & $\mathrm{T}$ & $\mathrm{G}$ & C & A & $\mathrm{A}$ & $\mathrm{G}$ & $\mathrm{T}$ & A \\
\hline $\mathrm{G}$ & $\mathrm{C}$ & $\mathrm{A}$ & $\mathrm{C}$ & $\mathrm{C}$ & - & $\mathrm{G}$ & $\mathrm{G}$ & A & $\mathrm{G}$ & $\mathrm{T}$ & $\mathrm{A}$ & A & $\mathrm{G}$ & $\mathrm{T}$ & $\mathrm{T}$ & $\mathrm{T}$ & $\mathrm{A}$ & $\mathrm{T}$ & $\mathrm{G}$ & $\mathrm{G}$ & $\mathrm{G}$ & $\mathrm{G}$ & $\mathrm{C}$ & $\mathrm{G}$ & $\mathrm{A}$ & $\mathrm{T}$ & $\mathrm{G}$ & $\mathrm{C}$ & A & $\mathrm{A}$ & $\mathrm{G}$ & $\mathrm{T}$ & A \\
\hline $\mathrm{H}$ & $\mathrm{C}$ & $\mathrm{A}$ & C & $\mathrm{C}$ & - & G & $\mathrm{G}$ & A & G & $\mathrm{C}$ & $\mathrm{A}$ & $\mathrm{A}$ & G & $\mathrm{T}$ & $\mathrm{T}$ & $\mathrm{T}$ & $\mathrm{A}$ & $\mathrm{T}$ & G & G & $A$ & G & C & G & $\mathrm{A}$ & $\mathrm{T}$ & G & C & A & $\mathrm{A}$ & $\mathrm{G}$ & $\mathrm{T}$ & A \\
\hline I & $\mathrm{C}$ & A & C & $\mathrm{T}$ & - & $\mathrm{G}$ & G & $\mathrm{G}$ & G & $\mathrm{T}$ & $A$ & $\mathrm{~A}$ & G & $\mathrm{T}$ & $\mathrm{T}$ & $\mathrm{T}$ & A & $\mathrm{T}$ & G & G & $\mathrm{A}$ & G & $\mathrm{C}$ & $\mathrm{G}$ & A & $\mathrm{T}$ & G & C & A & $A$ & $\mathrm{G}$ & $\mathrm{T}$ & A \\
\hline $\mathrm{J}$ & $\mathrm{C}$ & A & C & $\mathrm{C}$ & - & G & G & A & G & $\mathrm{T}$ & $\mathrm{A}$ & A & G & $\mathrm{T}$ & $\mathrm{T}$ & $\mathrm{T}$ & $\mathrm{A}$ & $\mathrm{T}$ & G & G & $\mathrm{A}$ & G & $\mathrm{C}$ & G & $\mathrm{A}$ & $\mathrm{T}$ & G & C & A & $\mathrm{G}$ & $\mathrm{G}$ & $\mathrm{T}$ & A \\
\hline $\mathrm{K}$ & $\mathrm{T}$ & G & $\mathrm{T}$ & $\mathrm{T}$ & $\mathrm{T}$ & $\mathrm{A}$ & $\mathrm{G}$ & $A$ & A & $\mathrm{C}$ & $\mathrm{A}$ & A & $\mathrm{G}$ & $\mathrm{C}$ & $\mathrm{T}$ & $\mathrm{C}$ & $\mathrm{G}$ & $\mathrm{C}$ & $\mathrm{A}$ & - & $\mathrm{A}$ & $\mathrm{A}$ & $\mathrm{T}$ & $\mathrm{A}$ & $\mathrm{A}$ & $\mathrm{C}$ & - & - & - & - & - & - & A \\
\hline $\mathrm{L}$ & $\mathrm{C}$ & A & $\mathrm{C}$ & $\mathrm{C}$ & - & $\mathrm{A}$ & G & $\mathrm{A}$ & G & $\mathrm{T}$ & $\mathrm{A}$ & $\mathrm{A}$ & G & $\mathrm{T}$ & $\mathrm{T}$ & $\mathrm{T}$ & $A$ & $\mathrm{~T}$ & G & G & $A$ & G & $\mathrm{C}$ & $\mathrm{G}$ & $\mathrm{A}$ & $\mathrm{T}$ & G & $\mathrm{C}$ & A & $\mathrm{G}$ & $\mathrm{G}$ & $\mathrm{T}$ & A \\
\hline $\mathrm{M}$ & C & $\mathrm{A}$ & C & $\mathrm{C}$ & - & $\mathrm{G}$ & $A$ & $\mathrm{~A}$ & G & $\mathrm{T}$ & $\mathrm{A}$ & $\mathrm{A}$ & G & $\mathrm{T}$ & $\mathrm{T}$ & $\mathrm{T}$ & $\mathrm{A}$ & $\mathrm{T}$ & G & G & $\mathrm{A}$ & G & $\mathrm{C}$ & $\mathrm{G}$ & $\mathrm{A}$ & $\mathrm{T}$ & $\mathrm{G}$ & C & $\mathrm{A}$ & A & $\mathrm{G}$ & $\mathrm{T}$ & A \\
\hline $\mathrm{N}$ & $\mathrm{T}$ & G & $\mathrm{T}$ & $\mathrm{T}$ & $\mathrm{T}$ & A & $\mathrm{A}$ & A & $\mathrm{A}$ & $\mathrm{C}$ & $\mathrm{A}$ & A & $\mathrm{G}$ & $\mathrm{C}$ & $\mathrm{T}$ & $\mathrm{C}$ & $\mathrm{A}$ & $\mathrm{C}$ & $\mathrm{A}$ & - & $A$ & $\mathrm{~A}$ & $\mathrm{~T}$ & A & A & $\mathrm{C}$ & - & - & - & - & - & - & A \\
\hline $\mathrm{O}$ & $\mathrm{T}$ & $\mathrm{G}$ & $\mathrm{T}$ & $\mathrm{T}$ & $\mathrm{T}$ & A & $\mathrm{G}$ & A & A & $\mathrm{C}$ & G & $\mathrm{A}$ & $\mathrm{G}$ & C & $\mathrm{C}$ & $\mathrm{C}$ & G & $\mathrm{C}$ & $\mathrm{A}$ & - & $\mathrm{A}$ & $\mathrm{A}$ & $\mathrm{T}$ & A & $\mathrm{A}$ & $\mathrm{C}$ & - & - & - & - & - & - & A \\
\hline $\mathrm{P}$ & $\mathrm{C}$ & $\mathrm{A}$ & $\mathrm{C}$ & $\mathrm{C}$ & - & $\mathrm{G}$ & $\mathrm{G}$ & A & G & $\mathrm{T}$ & $\mathrm{A}$ & $\mathrm{A}$ & G & $\mathrm{T}$ & $\mathrm{T}$ & $\mathrm{T}$ & $\mathrm{A}$ & $\mathrm{T}$ & G & G & $A$ & $\mathrm{G}$ & $\mathrm{C}$ & $\mathrm{G}$ & $\mathrm{A}$ & $\mathrm{T}$ & $\mathrm{G}$ & $\mathrm{C}$ & A & $\mathrm{A}$ & $\mathrm{G}$ & $\mathrm{C}$ & A \\
\hline $\mathrm{Q}$ & $\mathrm{T}$ & G & $\mathrm{T}$ & $\mathrm{T}$ & $\mathrm{T}$ & $\mathrm{A}$ & $\mathrm{G}$ & A & $\mathrm{A}$ & $\mathrm{C}$ & G & G & $\mathrm{G}$ & $\mathrm{C}$ & $\mathrm{T}$ & $\mathrm{C}$ & G & $\mathrm{C}$ & $\mathrm{A}$ & - & $\mathrm{A}$ & $\mathrm{A}$ & $\mathrm{T}$ & $\mathrm{A}$ & $\mathrm{A}$ & $\mathrm{C}$ & - & - & - & - & - & - & A \\
\hline
\end{tabular}

eries to sea turtle populations on foraging grounds (Broderick et al. 1994, Bowen 1995a, $b$, Bowen et al. 1995, 1996, Sears et al. 1995). Results of ML analyses on the 121 samples that could be matched to rookery haplotypes (Table 3 ) indicate that the pelagic loggerheads were derived from nesting populations in the northwest Atlantic. Estimated contributions from $\mathrm{UCON}$ analysis are $0.71 \pm 0.11$ (mean $\pm 1 \mathrm{SD}$ ) from south Florida, $0.19 \pm 0.08$ from the region between northeast Florida and North Carolina, and $0.11 \pm 0.04$ from Mexico. Estimates from SHADRACQ analysis are similar (Table 3).

An important caveat to these estimates is that the ML model assumes that all potential source populations have been sampled and that all rookery haplotypes are known. Because this assumption is unlikely to be met for any migratory marine species with widely scattered breeding areas, some caution is indicated in interpreting natural history patterns on the basis of results of the model. Therefore, despite the zero contribution from Greece and Brazil indicated by the ML analyses, we cannot eliminate the possibility of a small contribution from these rookeries to the pelagic population.

The estimated contributions from the four northwestern Atlantic rookeries are consistent with the relative sizes of these four nesting populations, based on field studies. Estimates of relative numbers of nests (Zurita et al. 1993, Meylan et al. 1995) are: $88 \%$ from

TABLE 2. Distribution of mtDNA haplotypes (letter code) in Azores and Madeira pelagic juvenile loggerhead populations and six Atlantic loggerhead nesting populations. Rookery abbreviations are as in Fig. 1.

\begin{tabular}{|c|c|c|c|c|c|c|c|c|}
\hline Letter code & Azores & Madeira & NWFL & $\begin{array}{l}\text { South } \\
\text { Florida }\end{array}$ & $\begin{array}{c}\text { NEFL- } \\
\text { NC }\end{array}$ & Mexico & Greece & Brazil \\
\hline A & 36 & 24 & 34 & 22 & 104 & & & \\
\hline B & 31 & 19 & 4 & 24 & 1 & 11 & 19 & \\
\hline $\mathrm{C}$ & 5 & 2 & 2 & 2 & & 2 & & \\
\hline D & & & & & & & & 11 \\
\hline E & & & & 1 & & & & \\
\hline F & & & & & & & 2 & \\
\hline G & & & 2 & 1 & & & & \\
\hline $\mathrm{H}$ & 1 & & & & & 1 & & \\
\hline I & & & & & & 1 & & \\
\hline $\mathrm{J}$ & & 3 & & & & 5 & & \\
\hline K & & 1 & & & & & & \\
\hline $\mathrm{L}$ & & 1 & & & & & & \\
\hline $\mathrm{M}$ & 2 & & & & & & & \\
\hline $\mathrm{N}$ & 2 & 1 & & & & & & \\
\hline $\mathrm{O}$ & 1 & & & & & & & \\
\hline $\mathrm{P}$ & 1 & & & & & & & \\
\hline $\mathrm{Q}$ & & 1 & & & & & & \\
\hline Total & 79 & 52 & 42 & 50 & 105 & 20 & 21 & 11 \\
\hline
\end{tabular}




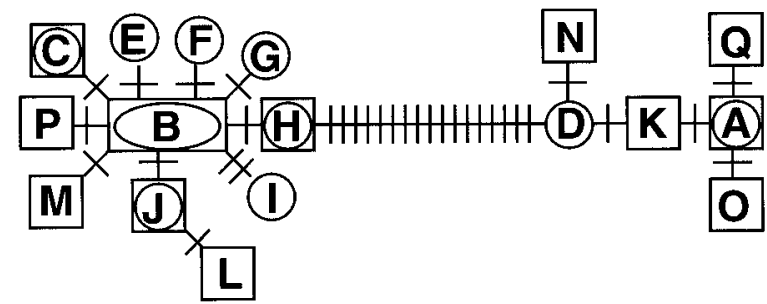

FIG. 2. Parsimony network indicating the relationships among 17 haplotypes observed in Atlantic loggerhead turtles Insertions/deletions are treated as single nucleotide substitutions. Circles indicate the haplotypes observed in nesting areas, and squares indicate the haplotypes observed in pelagic samples. The five haplotypes $(\mathrm{A}, \mathrm{B}, \mathrm{C}, \mathrm{H}$, and $\mathrm{J})$ that are shared between nesting and pelagic juvenile populations account for $95 \%$ of samples collected in the northern hemisphere and $92 \%$ of samples collected in the pelagic study sites (Table 2).

south Florida, $8 \%$ from northeast Florida to North Carolina, 3\% from Mexico, and 1\% from northwest Florida. It should be noted, however, that estimates of numbers of nests are approximate, because of unequal monitoring efforts and great year-to-year variation in reproductive effort. Nonetheless, there is general agreement between rookery size and estimated contribution to juvenile feeding grounds.

\section{Transoceanic migration hypothesis}

The contributions estimated by ML analyses support the hypothesis that the primary source of juvenile loggerheads in the eastern Atlantic is the nesting beaches in the northwest Atlantic. The homogeneity between the haplotype frequencies of the Azores and Madeira samples is also consistent with the hypothesized route of travel: posthatchling loggerheads are carried by the North Atlantic gyre from the coast of the southeastern United States to the Azores and past Madeira and the Canary Islands before returning to western Atlantic waters. Captures of individual tagged loggerheads have documented movement from Madeira to the Canary Islands (Bjorndal et al. 1994), from the Canary Islands to the northwest Atlantic (Bolten et al. 1992a), and from the Azores to the northwest Atlantic (A. B. Bolten, K. A. Bjorndal, and H. R. Martins, unpublished data). Evidence from recapture of tagged turtles and genetic markers indicates that some loggerheads enter the western Mediterranean after passing by the Azores during their developmental migrations, but the magnitude of this cohort remains unknown (Bolten et al. 1992b, Bowen et al. 1993, Laurent et al. 1993, Bowen $1995 b)$. Satellite telemetry now in progress will elucidate the specific movement patterns of pelagic loggerheads in the eastern Atlantic (A. B. Bolten, K. A. Bjorndal, and H. R. Martins, unpublished data).

The six surveyed nesting populations represent the vast majority of nesting effort in the Atlantic and Mediterranean basins. However, of the 131 pelagic juvenile loggerheads that we sampled, $10(8 \%)$ had haplotypes
TABle 3. Mean contribution of nesting populations to the Azores and Madeira pelagic juvenile population, as estimated by unconditional maximum likelihood analyses (UCON and SHADRACQ). SHADRACQ does not generate confidence intervals. Rookery abbreviations are as in Fig. 1.

\begin{tabular}{lcc}
\hline \hline Population & $\begin{array}{c}\text { UCON } \\
\text { contribution }(1 \mathrm{SD})\end{array}$ & $\begin{array}{c}\text { SHADRACQ } \\
\text { contribution }\end{array}$ \\
\hline NWFL & $0.00(0.00)$ & 0.00 \\
South Florida & $0.71(0.11)$ & 0.72 \\
NEFL-NC & $0.19(0.08)$ & 0.17 \\
Mexico & $0.11(0.04)$ & 0.10 \\
Greece & $0.00(0.00)$ & 0.00 \\
Brazil & $0.00(0.00)$ & 0.00 \\
\hline
\end{tabular}

that were not detected in Atlantic loggerhead nesting populations and, therefore, could not be included in the maximum likelihood analyses. These seven new haplotypes were all observed at low frequency (Table 2): five haplotypes were represented by only a single animal, and haplotype $\mathrm{N}$ had the highest frequency, observed in three turtles. These rare haplotypes may have been missed in the genetic survey of nesting populations, or they may occur in small nesting populations that have not yet been sampled. In the western Atlantic, small numbers of loggerheads nest in areas, such as the Bahamas and Cuba, that have not been sampled because of logistic or political restrictions. Small nesting populations along the west coast of Africa and in the Mediterranean also remain to be sampled. Although samples from these remaining nesting populations would be informative and might provide some of the missing rare haplotypes, results of such work would be unlikely to alter our conclusion that the northwestern Atlantic rookeries are the primary sources of juvenile pelagic loggerheads in the eastern Atlantic, because these populations are too small to produce the large number of juvenile loggerheads in the eastern Atlantic. The five haplotypes (A, B, C, H, and J) that are shared between nesting and pelagic populations account for 95\% of samples collected in the northern hemisphere (Table 2).

Genetic markers and recaptures of tagged turtles indicate that a similar migratory pattern exists in the Pacific (Bowen et al. 1995, and references cited therein). Loggerhead hatchlings leave nesting beaches in Japan, and perhaps Australia, and undertake developmental migrations that carry them to the eastern $\mathrm{Pa}$ cific, including the waters off Baja California. Because transoceanic migrations are now documented for the North Atlantic and North Pacific, we suggest that such migrations may be a general phenomenon for loggerhead populations, and that similar movement patterns may be expected in the South Atlantic, South Pacific, and Indian oceans. Whether transoceanic developmental migrations are undertaken by other species of sea turtles remains to be determined. 


\section{Management implications}

Loggerhead turtles face a number of threats in the pelagic waters of the eastern Atlantic. The same physical forces that tend to concentrate small turtles in convergence zones (the biologically active boundaries between currents and/or water masses) also concentrate floating debris, thereby increasing the chance of ingestion or entanglement (Carr 1987). Incidental capture in fisheries, particularly longline fisheries, is another substantial source of mortality (Bolten et al. 1994). Incidental capture of juvenile loggerheads on longline fisheries in the Mediterranean is estimated to be 20000 juveniles/yr (Aguilar et al. 1995). These additional sources of mortality can now be included in demographic models developed to monitor responses of Atlantic loggerhead populations to management policies (Crouse et al. 1987, Crowder et al. 1994).

The Atlantic loggerhead is protected under a number of international conventions (e.g., CITES and the Bern Convention) and under legislation in individual nations. Tremendous resources have been invested in protecting U.S. loggerhead populations, both on nesting beaches and in nearshore waters (National Research Council 1990, National Marine Fisheries Service and U.S. Fish and Wildlife Service 1991), although such efforts have not afforded complete protection (National Research Council 1990). However, even complete protection in one region may not be sufficient to save a population if excessive exploitation or mortality occurs in other geographic areas. Effective management of loggerhead turtles in the Atlantic will require a regional approach with multinational cooperation. Transoceanic migrations invoke the need for transoceanic management plans.

Molecular genetic markers have powerful applications in the resolution of migratory patterns in marine turtles, and this approach may prove useful in other migratory species. In this case, mtDNA markers confirm the suspected demographic link between loggerhead nesting colonies in the west Atlantic and juvenile feeding aggregates in the east Atlantic. We remain ignorant, however, of the distribution of young pelagicstage turtles for all other sea turtle populations, other than the North Pacific loggerhead (Bowen et al. 1995). To ensure the survival of remaining sea turtle populations, high priority should be given to discovering and characterizing these missing life stages.

\section{ACKNOWLEDGMENTS}

This work was funded by the Marine Entanglement Research Program of the U.S. National Marine Fisheries Service through Research Work Orders 66 and 118 of the Florida Cooperative Fish and Wildlife Research Unit (National Biological Service) to K. A. Bjorndal and A. B. Bolten. Additional support was provided by the University of the Azores, Department of Oceanography and Fisheries, and by the University of Madeira.

For their support of this project, we thank J. Coe, J. and G. Franck (M.V. Shanghai), B. Herbert, L. Steiner, S. Viallelle, W. Thompson, and our valued colleagues, especially
Carmelina Leal and Equipa Tartaruga, R.V. Aguas Vivas, at the Department of Oceanography and Fisheries, University of the Azores, and Renato Barradas at the University of Madeira. The Secretariat of Agriculture and Fisheries of the Regional Government of the Azores supported the participation of the commercial fishing fleet based in Horta. For technical support, we thank the DNA Sequencing Core and the Biotechnology Center at the University of Florida, A. L. Bass, A. M. Clark, R. Ferl, S. Shanker, and E. Almira. We thank P. Smouse and C. J. Kobak for sharing their unpublished program (SHADRACQ).

All necessary research permits and CITES export and import permits were obtained. All animal care was in full compliance with the University of Florida Institutional Animal Care and Use Committee.

\section{Literature Cited}

Aguilar, R., J. Mas, and X. Pastor. 1995. Impact of Spanish swordfish longline fisheries on the loggerhead sea turtle Caretta caretta population in the western Mediterranean. Pages 1-6 in J. I. Richardson and T. H. Richardson, compilers. Proceedings of the Twelfth Annual Workshop on Sea Turtle Biology and Conservation. NOAA Technical Memorandum NMFS-SEFSC-361, Miami, Florida, USA.

Avise, J. C. 1994. Molecular markers, natural history, and evolution. Chapman and Hall, New York, New York, USA.

Baker, C. S., R. W. Slade, J. L. Bannister, R. B. Abernethy, M. T. Weinrich, J. Lien, J. Urban, P. Corkeron, J. Calmabokidis, O. Vasquez, and S. R. Palumbi. 1994. Hierarchical structure of mitochondrial DNA gene flow among humpback whales, Megaptera novaeangliae, worldwide. Molecular Ecology 3:313-327.

Bjorndal, K. A., A. B. Bolten, J. Gordon, and J. A. Camiñas. 1994. Caretta caretta (loggerhead) growth and pelagic movement. Herpetological Review 25:23-24.

Bolten, A. B., and G. H. Balazs. 1995. Biology of the early pelagic stage: the "lost year." Pages 575-581 in K. A. Bjorndal, editor. Biology and conservation of sea turtles, revised edition. Smithsonian Institution Press, Washington, D.C., USA.

Bolten, A. B., K. A. Bjorndal, and H. R. Martins. 1994. Life history model for the loggerhead sea turtle (Caretta caretta) population in the Atlantic: potential impacts of a longline fishery. Pages 48-54 in G. H. Balazs and S. G. Pooley, editors. Research plan to assess marine turtle hooking mortality. NOAA Technical Memorandum NMFS-SWFSC201, Miami, Florida, USA.

Bolten, A. B., H. R. Martins, K. A. Bjorndal, M. Cocco, and G. Gerosa. 1992b. Caretta caretta (loggerhead) pelagic movement and growth. Herpetological Review 23:116.

Bolten, A. B., H. R. Martins, K. A. Bjorndal, and J. Gordon. 1993. Size distribution of pelagic-stage loggerhead sea turtles (Caretta caretta) in the waters around the Azores and Madeira. Arquipélago 11A:49-54.

Bolten, A. B., C. Santana, and K. A. Bjorndal. 1992a. Transatlantic crossing by a loggerhead turtle. Marine Turtle Newsletter 59:7-8.

Bowen, B. W. 1995a. Molecular genetic studies of marine turtles. Pages 585-587 in K. A. Bjorndal, editor. Biology and conservation of sea turtles, revised edition. Smithsonian Institution Press, Washington, D.C., USA.

. 1995b. Tracking marine turtles with genetic markers: voyages of the ancient mariners. BioScience 45:528-534.

Bowen, B. W., F. A. Abreu-Grobois, G. H. Balazs, N. Kamezaki, C. J. Limpus, and R. J. Ferl. 1995. Trans-Pacific migrations of the loggerhead turtle (Caretta caretta) demonstrated with mitochondrial DNA markers. Proceedings of the National Academy of Sciences (USA) 92:37313734.

Bowen, B. W., J. C. Avise, J. I. Richardson, A. B. Meylan, D. Margaritoulis, and S. R. Hopkins-Murphy. 1993. Pop- 
ulation structure of loggerhead turtles (Caretta caretta) in the northwestern Atlantic Ocean and Mediterranean Sea. Conservation Biology 7:834-844.

Bowen, B. W., A. L. Bass, A. Garcia-Rodriquez, C. E. Diez, R. van Dam, A. B. Bolten, K. A. Bjorndal, M. M. Miyamoto, and R. J. Ferl. 1996. Origin of hawksbill turtles in a Caribbean feeding area as indicated by genetic markers. Ecological Applications 6:566-572.

Broderick, D., C. Moritz, J. D. Miller, M. Guinea, R. J. Prince, and C. J. Limpus. 1994. Genetic studies of the hawksbill turtle (Eretmochelys imbricata): evidence for multiple stocks in Australian waters. Pacific Conservation Biology 1:123-131.

Brongersma, L. D. 1972. European Atlantic turtles. Zoologische Verhandelingen, Uitgegeven door het Rijksmuseum van Natuurlijke Historie te Leiden, Number 121.

Carr, A. 1975. The Ascension Island green turtle colony. Copeia 1975:547-555.

1982. Notes on the behavioral ecology of sea turtles. Pages 19-26 in K. A. Bjorndal, editor. Biology and conservation of sea turtles. Smithsonian Institution Press, Washington, D.C., USA.

. 1986. Rips, FADS, and little loggerheads. BioScience 36:92-100.

. 1987. Impact of nondegradable marine debris on the ecology and survival outlook of sea turtles. Marine Pollution Bulletin 18:352-356.

Crouse, D. T., L. B. Crowder, and H. Caswell. 1987. A stagebased population model for loggerhead sea turtles and implications for conservation. Ecology 68:1412-1423.

Crowder, L. B., D. T. Crouse, S. S. Heppell, and T. H. Martin 1994. Predicting the impact of turtle excluder devices on loggerhead sea turtle populations. Ecological Applications 4:437-445.

Ehrhart, L. M. 1982. A review of sea turtle reproduction Pages 29-38 in K. A. Bjorndal, editor. Biology and conservation of sea turtles. Smithsonian Institution Press, Washington, D.C., USA.

Encalada, S. E., K. A. Bjorndal, A. B. Bolten, J. C. Zurita, B. Schroeder, E. Possardt, C. Sears, and B. W. Bowen. In press. Population structure of loggerhead turtle (Caretta caretta) nesting colonies in the Atlantic and Mediterranean regions as inferred from mitochondrial DNA control region sequences. Marine Biology.

Hillis, D., C. Moritz, and B. K. Mable. 1996. Molecular systematics, second edition. Sinauer Associates, Sunderland, Massachusetts, USA.

Laurent, L., J. Lescure, L. Excoffier, B. Bowen, M. Domingo, M. Hadjichristophorou, L. Kornaraki, and G. Trabuchet. 1993. Étude génétique des relations entre les populations méditerranéenne et atlantique d'une tortue marine (Caretta caretta) à l'aide d'un marqueur mitochondrial. Comptes Rendus de l'Academie des Sciences (Paris), Sciences de la Vie 316:1233-1239.

Limpus, C. J., J. D. Miller, C. J. Parmenter, D. Reimer, N. McLachlan, and R. Webb. 1992. Migration of green (Chelonia mydas) and loggerhead (Caretta caretta) turtles to and from eastern Australian rookeries. Wildlife Research 19:347-358

Meylan, A. B. 1982. Sea turtle migration: evidence from tag returns. Pages 91-100 in K. A. Bjorndal, editor. Biology and conservation of sea turtles. Smithsonian Institution Press, Washington, D.C., USA.

Meylan, A., B. Schroeder, and A. Mosier. 1995. Sea turtle nesting activity in the State of Florida. Florida Marine Research Publications 52:1-51.

Mitchell, L. G., and C. R. Merrill. 1989. Affinity generation of single-stranded DNA for dideoxy sequencing following the polymerase chain reaction. Analytical Biochemistry 178: $239-242$

Mullis, K. B., and F. Faloona. 1987. Specific synthesis of DNA in vitro via polymerase-catalyzed chain reaction. Methods in Enzymology 155:335-350.

National Marine Fisheries Service (NMFS) and U.S. Fish and Wildlife Service. 1991. Recovery plan for U.S. population of loggerhead turtle. National Marine Fisheries Service, Washington, D.C., USA.

National Research Council. 1990. Decline of sea turtles: causes and prevention. National Academy of Sciences, Washington, D.C., USA.

Norman, J. A., C. Moritz, and C. J. Limpus. 1994. Mitochondrial DNA control region polymorphisms: genetic markers for ecological studies of marine turtles. Molecular Ecology 3:363-373.

Pella, J. J., and G. B. Milner. 1987. Use of genetic marks in stock composition analysis. Pages $247-276$ in N. Ryman and F. W. Utter, editors. Population genetics and fisheries management. University of Washington Press, Seattle, Washington, USA.

Sanger, F., S. Nicklen, and A. R. Coulson. 1977. DNA sequencing with chain-terminating inhibitors. Proceedings of the National Academy of Sciences (USA) 74:5463-5467.

Sears, C. J., B. W. Bowen, R. W. Chapman, S. B. Galloway, S. R. Hopkins-Murphy, and C. M. Woodley. 1995. Demographic composition of the feeding population of juvenile loggerhead sea turtles (Caretta caretta) off Charleston, South Carolina: evidence from mitochondrial DNA markers. Marine Biology 123:869-874.

Smouse, P. E., R. S. Waples, and J. A. Tworek. 1990. A genetic mixture analysis for use with incomplete source population data. Canadian Journal of Fisheries and Aquatic Sciences 47:620-634.

White, P. S., and L. D. Densmore, III. 1992. Mitochondrial DNA isolation. Pages 29-58 in A. R. Hoelzel, editor. Molecular genetic analysis of populations: a practical approach. IRL Press at Oxford University Press, New York, New York, USA

Xu, S., C. J. Kobak, and P. E. Smouse. 1994. Constrained least squares estimation of mixed population stock composition from mtDNA haplotype frequency data. Canadian Journal of Fisheries and Aquatic Sciences 51:417-425.

Zaykin, D. V., and A. I. Pudovkin. 1993. Two programs to estimate chi-square values using pseudoprobability test. Journal of Heredity 84:152.

Zurita, J. C., R. Herrera, and B. Prezas. 1993. Tortugas marinas del Caribe. Pages 735-750 in S.I. Salazar-Vallejo and N. E. González, editors. Biodiversidad marina y costera de México. Comision Nacional para el Conocimiento y Aprovechamiento de la Biodiversidad, Centro de Investigaciones de Quintana Roo, México. 